\title{
"Time to Reflect": Enhancing the self-efficacy of secondary school wellbeing personnel in recognising and responding to mental health needs of students
}

\author{
Carsten Schley · Lisa McKay-Brown · Judy Ring · Katherine Monson · Jo Robinson · \\ Leanne Crothers · Joanne Moore
}

\begin{abstract}
Time to Reflect" (TTR) is an innovative five-session professional development program for secondary school wellbeing personnel working with students between the ages of 12 and 18 . TTR is jointly designed and delivered by an educational and a youth mental health specialist service. The program provides education on a range of mental health related topics and offers participants an opportunity to reflect on their current practices. The primary aim of this study was to evaluate whether the TTR program increases perceived competence and confidence of participants in recognising and responding to the mental health needs of students. The secondary aim was to assess changes in the use of reflection and its perceived benefits for professional practice. Participants completed a self-assessment questionnaire at three time points: prior to the first session, after the final session, and three months after completion of the program. One hundred and thirty-five school wellbeing personnel from a variety of state, independent, and Catholic secondary schools participated. Following completion of the program, participants reported significantly greater confidence and competence in helping students with mental health problems, with this level of change being maintained at the three-month post-training assessment. The majority of participants reported positive changes in their use of reflection, and consequent benefits to their professional practice. The findings from this study suggest that the TTR program promoted the self-efficacy of participants in responding to the mental health needs of students, and that regular reflective practice may be an effective and beneficial model for continued professional learning and development in schools.
\end{abstract}

Keywords: mental health, school wellbeing, professional development, reflective practice

\section{Background}

Mental health problems in secondary school-aged students are very common (AIHW, 2007/2011), and school wellbeing personnel are often the first point of call for young people seeking assistance (Graham et al., 2011; Walter, Gouze \& Lim, 2006). Yet many school wellbeing staff members do not have specific mental health training or the support (e.g. regular supervision) to equip them with the necessary skills to appropriately assist these students (Partridge, 2012). Apart from social workers and psychologists working in schools, school wellbeing personnel can include teachers in the role of head of house, pastoral workers, year level or welfare coordinators, along with nurses, and youth workers. Many of these practitioners have not had specific training in recognising and managing student mental health concerns (Rothi et al., 2008; Trudgen \& Lawn, 2011; Walter et al., 2006). Specifically, this may include understanding and managing risk 
around youth suicide (Crawford \& Caltabiano, 2009; Koller \& Bertel, 2006), identifying students with internalising problems (Vieira et al., 2014) and getting appropriate help for students (Koller \& Bertel, 2006), particularly those with more challenging mental health needs. Carlson and Kees (2013) also report that school counsellors were generally less comfortable working with students with a diagnosed mental illness. Trudgen and Lawn (2011) found that teachers working as year level coordinators or head of house were no more likely to have increased knowledge of youth mental health problems than the general teaching group, despite their role as referral points for concern. Additionally, wellbeing personnel sit with the tension of providing for the health and wellbeing needs of students within an organisation focused on the provision of education (Hopkins, 2014) and achieving academic results.

Partridge (2012) identified that school staff frequently report challenges to their own wellbeing when managing the mental health needs of their students, and that offering assistance to meet staff members' own wellbeing needs can enhance their ability to look after the wellbeing needs of their students. Individual staff wellbeing issues commonly involve: a sense of isolation (Graham et al., 2011); a struggle to meet the demands of their role (Carlson \& Kees, 2013); lack of confidence (Walter et al., 2006); feelings of incompetence, frustration and helplessness (Rothi et al., 2008); and psychological distress (Borntrager et al., 2012).

The "Time to Reflect" (TTR) training program was developed with the aim of promoting the perceived competence and confidence of school wellbeing personnel in recognising and responding to the mental health needs of their students. TTR was jointly conceived and developed by Travancore School and Orygen Youth Health (OYH) in 2004. Orygen Youth Health is a publicly funded youth mental health service based in Melbourne, Australia. It has a specialised youth mental health clinical service and an integrated training and communications program. Travancore School is a Victorian Department of Education and Training Special Education setting, offering a unique educational service to support the learning needs of young people with significant mental health difficulties. The school works with both Orygen Youth Health and The Royal Children's Hospital Mental Health.

The TTR partnership between OYH and Travancore School was founded on the desire to bring together knowledge in youth mental health and expertise in the education of young people with mental health issues. Calls for mental health services to work more closely with schools are common (Weist et al., 2012), but successful organisational structures upon which to build such collaborative relationships are less evident. Partnerships between the educational and mental health sectors have been known to lead to improvements in wellbeing for students and school communities (Pettitt, 2003). However, challenges to the development of collaborative partnerships can include a lack of knowledge of mental health issues and systems within schools, combined with a lack of understanding of the education system amongst mental health professionals (Rothi et al., 2008). The delivery of training in mental health for the education sector would ideally take into account these challenges and draw from successful partnerships across sectors.

The TTR program aimed to ensure inclusion of the content most relevant to wellbeing personnel, and also to deliver content in an acceptable and meaningful way to this school-based audience. The TTR program was the result of a true interdisciplinary collaboration between an education service and a mental health service. Consistent with the model described by Bronstein (2003), Orygen Youth Health and Travancore School collaborated to achieve goals that would not be possible for one service working alone. 


\subsection{Why "Time to Reflect"?}

"Reflection" (on action) is a method that supports professional learning (e.g. Atkins and Murphy, 1993; Boud, Keogh \& Walker, 1985; Schön, 1987), with its benefits widely recognised and promoted (e.g. Larrivee, 2000; Mann, Gordon \& MacLeod, 2009). Hillkirk, Tome and Wandress (1989, cited in Srivastava et al., 2015) define reflection as a "conscious and intentional examination of the behaviour, ideas and feelings generated by a learning experience with the purpose of increasing the experience's usefulness to the learner" (p.153). By including a reflective practice framework in the TTR program, as shown in Figure 1, the course developers aimed to support participants to critically appraise work practices and to stimulate new ideas about how to enhance their skills in responding to the mental health needs of students.

Figure 1. Reflective model used in TTR (adaptation from Gibbs, 1988)

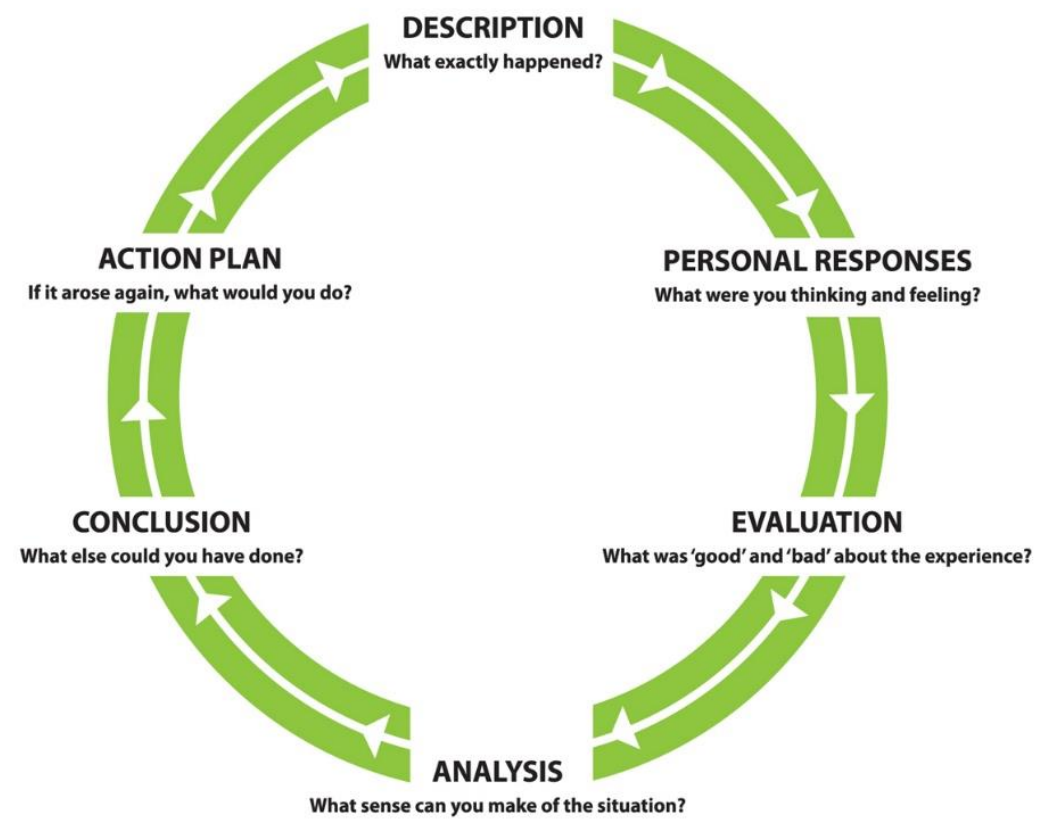

The reflective component of the TTR program specifically aimed to:

1) Provide a model to structure reflection. The "reflective practice model" underlying the TTR training series was adapted from the work of Gibbs (1988) who proposed a "circular process (model) of reflection" (Figure 1). This model was selected, as it encourages an individual not only to "objectively" describe a situation (i.e. what they did exactly) but also to evaluate their personal responses at the time (i.e. what they were thinking and feeling).

2) Build in opportunities to practice and refine reflective skills (Lee \& Barnett, 1994) because allocating time for professional collaboration and reflection has been linked to improved effectiveness (Bronstein, 2003).

3) Encourage a move from "reactive" to "proactive" practice. The culture in schools often encourages a quick solution to problems rather than the development of a deeper understanding of the issues (Korthagen \& Vasalos, 2006); in other words, committing to a belief without reflection can prevent a deeper understanding (Carroll \& Gilbert, 2011). 
4) Reduce the isolation of wellbeing workers in managing complex student issues through regular reflection with colleagues. The level of secondary traumatic stress reported in school personnel is comparable to that of social workers and has been shown to benefit from explicit peer support activities (Borntrager et al., 2012; Partridge, 2012).

5) Give attention to the role of feelings and emotions in understanding one's own behaviours (Carroll \& Gilbert, 2011; Korthagen \& Vasalos, 2006) and to understand the link between personal perceptions and behavioural responses (Larrivee, 2000). Emotional containment can provide the platform for new understanding and reduced anxiety (Partridge, 2012).

6) Move beyond a problem-centred focus to being able to explore new possibilities (Korthagen \& Vasalos, 2006), including seeing the positives within seemingly negative events (Larrivee, 2000).

7) Give opportunities to recognise good practice, build on strengths and develop confidence. Lee and Barnett (1994) highlight that the benefits gained from new understandings and perspectives are shared between active participants and reflective partners in their role of reflective questioner and active listener.

8) To reduce stress/distress by focusing on what is possible. The course developers anticipated that reflection on personal responses would allow TTR participants to make more sense of a complex situation and come to a conclusion of what else could be or could have been done, or what other paths could have been taken.

\subsection{TTR training program}

The TTR training program comprised five training sessions delivered fortnightly over 10 weeks. This delivery schedule was designed so that participants could participate in independent reflective practice between sessions. All training sessions were of three hours duration and included three parts: 1) education in relation to one or more specific mental health topics, 2) small or large group discussion and/or group activities, and 3) an opportunity for participants to "reflect" upon their current practices (Table 1 below).

The mental health topics included in the course were selected based on requests for professional development or consultation made by school welfare staff in contact with either Travancore School or OYH. Group discussion and activities were aimed at exploring existing understanding and knowledge of participants in relation to the mental health topic(s), and to practice or refine professional skills (e.g. in how to engage a student in conversation about their deliberate self-harm). The objective of "reflection" has been described above.

Achieving deep understanding in adult learning has been characterised by specific adult learning methods (Dunst, Trivette \& Hanby, 2010). These include a planning phase that introduces and illustrates materials, knowledge or practice; the application phase that includes practise and evaluation of materials, knowledge or practice; and deep understanding, where reflection and mastery of the learning takes place (Dunst, Trivette \& Hanby, 2010). All sessions included a range of activities and resources (e.g. video vignettes, worksheets, information sheets, links to online resources) that used these adult learning methods to support engagement and learning outcomes for participants. A reflective practice session between pairs of workshop participants ("reflective partners") was also scheduled after each training session to promote the development of reflective practice skills in between sessions, and to consolidate a reciprocal support structure between workshop participants, which could endure following completion of the workshop. 
Table 1a. Session outline of 'Time to Reflect' (TTR) training series

\begin{tabular}{|c|c|c|c|c|}
\hline Session 1 & Session 2 & Session 3 & Session 4 & Session 5 \\
\hline $\begin{array}{l}\text { Introduction \& overview } \\
\text { (30 min.) } \\
\text { - Pre-evaluation (20 min.) } \\
\text { - History of TTR } \\
\text { - Course outline/session } \\
\text { outline } \\
\text { - Activity: Participant } \\
\text { introduction } \\
\text { - Activity: Defining roles at } \\
\text { schools }\end{array}$ & $\begin{array}{l}\text { Reflection on previous } \\
\text { session \& session outline } \\
(10 \text { min.) }\end{array}$ & $\begin{array}{l}\text { Reflection on previous } \\
\text { session \& session outline } \\
(10 \text { min.) }\end{array}$ & $\begin{array}{l}\text { Reflection on previous } \\
\text { session \& session outline } \\
\text { (10 min.) }\end{array}$ & $\begin{array}{l}\text { Reflection on previous } \\
\text { session \& session outline } \\
(10 \text { min.) }\end{array}$ \\
\hline $\begin{array}{l}\text { Reflective practice (intro) } \\
\text { (30 min.) } \\
\text { - Concept definition \& } \\
\text { models } \\
\text { - Activity: "Reflection in } \\
\text { your school" - review of } \\
\text { existing experiences \& } \\
\text { processes } \\
\text { - Introduction to "Reflective } \\
\text { Model" (Gibbs, 1989) } \\
\text { - Facilitator demonstration } \\
\text { - Benefits/challenges of/with } \\
\text { reflection }\end{array}$ & $\begin{array}{l}\text { Engagement ( } 65 \text { min.) } \\
\text { - What is engagement? } \\
\text { - Engaging young people: } \\
\text { key areas } \\
\text { - Video vignette/activity: } \\
\text { "Engaging students at your } \\
\text { school" }\end{array}$ & $\begin{array}{l}\text { Youth suicide/deliberate } \\
\text { self-harm (DSH) (70 min.) } \\
\text { - Facts, terms, common } \\
\text { myths, "continuum of risk" } \\
\text { - Recognising risk \& how to } \\
\text { ask about suicide } \\
\text { - Video vignette/activity: } \\
\text { risk assessment } \\
\text { - Responding to suicide risk } \\
\text { in the school context } \\
\text { - Definition, prevalence of } \\
\text { DSH } \\
\text { - Video vignette/activity: } \\
\text { "What reasons for DSH can } \\
\text { you identify?" }\end{array}$ & $\begin{array}{l}\text { Challenging behaviours } \\
\text { (65 min.) } \\
\text { - What are challenging } \\
\text { behaviours? } \\
\text { - Activity: "Why are } \\
\text { challenging behaviours } \\
\text { difficult to work with?" } \\
\text { - Possible mental illness } \\
\text { diagnoses underlying } \\
\text { challenging behaviours } \\
\text { - A different theoretical } \\
\text { understanding of } \\
\text { challenging behaviours }\end{array}$ & $\begin{array}{l}\text { Eating disorders (55 min.) } \\
\text { - Definitions \& prevalence } \\
\text { - Signs of eating disorders } \\
\text { - Video vignette/activity: } \\
\text { "What signs of disordered } \\
\text { eating can you identify?" } \\
\text { - Causes: bio-psycho-social } \\
\text { model } \\
\text { - Treatment \& support } \\
\text { options (for schools) }\end{array}$ \\
\hline
\end{tabular}


Table 1b. Session outline of 'Time to Reflect' (TTR) training series

Session 1 Session 2

Youth depression (40 min.)

- Signs \& symptoms

- Incidence/prevalence

- Impact of depression

- Therapies for depression

- Practical support strategies

- Video vignette/activity: "How would you respond to 'Glen' at your school?"
Anxiety (40 min.)

- What is anxiety?

- Prevalence

- When is anxiety a problem?

- Overview of anxiety disorders

- Diagnosing an anxiety disorder

- Therapies \& practical strategies
Session 3

\section{Deliberate self-harm}

(40 min.)

- How to ask \& respond to DSH

- Management of DSH at school

- Personal response \& selfcare
Session 4

\section{Challenging behaviours} (cont) (35 min.)

- Ways of working with challenging behaviours

- Video vignette/activity: "The relationship." What contributes to effective behaviour management?

- Developing a positive behaviour plan

- Management issues specifically for schools

\section{Session 5}

Psychosis/partnerships with mental health services (20 min.)

- What is psychosis?

- Early warning signs for psychosis

- School responses \& strategies for supporting students with psychosis

- Referral to tertiary mental health services \& secondary consultation

- Post-evaluation (20 min.)

Reflective practice session (in pairs) \& large group discussion/review (35 min.)

Individual reflective journaling ("In relation to today's session, what will you KEEP, STOP and START doing in your work?") (5 min.)

Scheduling of in-between session reflection (5 min.)

Resources, conclusion \& wrap-up (10 min.) 


\subsection{The present study}

A systematic evaluation of the TTR training package was conducted between 2009 and 2013. The primary aim of this study was to explore whether the TTR training program would improve the perceived "competence" and "confidence" of participants in regards to the following key interest areas:

1) Recognition of mental health problems in young people

2) Helping students with a mental health problem (e.g. counselling and/or referral options)

3) Assessment of self-harm/suicide risk

4) Knowledge of appropriate interventions for mental health problems

5) Talking to parents about mental health problems.

Secondly, this study aimed to assess the possible benefits that adopting a "reflective approach" may have for the professional practice of participants.

\section{Methods}

\subsection{Research design and measures}

This study adopted a single group pre-test/post-test/maintenance design. Participants completed a self-assessment questionnaire at three time points (see Appendix 1): prior to the first session (T1), following the final session (T2), and three months after completing the program (T3). The questionnaire comprised the following measures:

Measure of change in perceived "competence" and "confidence." Participants were asked to assess their own competence (perceived ability/skill) and confidence (perceived certainty of ability/skill) in relation to the study's key interest areas, using a 5-point Likert Scale ranging from 1 (not at all) to 5 (extremely). For example, questions assessing competence included: "How skilled do you feel in your ability to recognise mental health problems in young people?" or "How skilled do you feel in assessing for risk of suicide or deliberate self-harm in young people?" Questions targeting perceived confidence included: "How confident do you feel in your ability to respond to students with a mental health problem?" or "How confident do you feel discussing mental health problems with parents of students at your school?" Participants were instructed to complete these self-assessments based on their level of perceived competence or confidence at the time of the rating.

Recognition of mental health disorders. The Mental Health Disorders Symptom Check (MHDSC) section of the questionnaire was developed by the study authors in order to assess participants' understanding of the signs and symptoms of the mental disorders that were discussed during the course. The MHDSC comprises a list of 29 "symptoms" corresponding to the criteria for major depression, generalised anxiety disorder, anorexia and bulimia nervosa, and schizophrenia, described in the DSM-IV-R (American Psychiatric Association, 1994). Participants were asked to identify those symptoms that they thought were indicative of each of four mental health disorders: depression, anxiety, eating disorder and psychosis (See Appendix 1, Section 5). The outcome measure of this questionnaire was the number of correct responses at each time point.

Perceived benefits of "reflective practice." To determine possible (perceived) benefits of reflective practice, participants were asked to rate how much they agreed with statements in relation to a number of previously published "benefits" of reflective practice (Larrivee, 2000; Mann et al., 2009; Atkins \& Murphy, 1993/1994). For example, participants were asked to what extent they thought that reflective practice could help with stimulating new ideas about how to enhance 
skills and practice (Atkins \& Murphy, 1994), or moving from "reactive" to more "proactive" practice (Korthagen \& Vasalos, 2006) using a 5-point Likert Scale ranging from 1 (not at all) to 5 (extremely). Using the same scale, participants also had to indicate how skilled they felt at reflecting on their professional practice, and how useful reflective practice was in their work. Additionally, participants were asked to quantify the time (in minutes) they allowed for reflection in a regular working week.

Professional practice change. The post-training (T2) and three-month follow-up (T3) questionnaire included two additional qualitative questions aimed at assessing potential changes to the participants' professional practice and their use of reflection. Participants were asked whether they had changed their practice and their use of reflection in any way since attending the training, and if so, to describe how. Conversely, if no change had occurred, participants were prompted to describe what may have prevented changes. In the T3 evaluation, participants were also asked whether they had been able to maintain any potential changes over the past three months (if applicable).

\subsection{Statistical analysis}

Data analyses were dependent on the measures used in each section of the questionnaires. Descriptive analysis was used for demographic data. Changes in ratings of "competence/confidence" and responses to the MHDSC were analysed by using the Friedman Test for subjects who had data in all of the time points concerned. This test was used to ascertain whether there were differences in the scores for the participants over three time points with a dependent variable that is ordinal. Post-hoc analysis comparing pairs of time points was conducted using the Wilcoxon Signed Ranks Test with a Bonferroni adjusted p-value of 0.016. This is an appropriate non-parametric post-hoc test to use when measuring differences in scores of the participants at two time points. Further analysis of the MHDSC used the Mann-Whitney $\mathrm{U}$ test to ascertain if there was any difference in responses between teachers and allied health professionals. To ascertain the level of agreement around the helpfulness of reflective practice, the Cochrane's Q Test was used to measure change across all three time points.

\subsection{Setting and sample}

A total of nine TTR workshops were run during the study period (two each during 2009, 2010, 2012 and 2013, and one during 2011). Recruitment of participants for all workshops occurred through local school welfare networks, web-based advertising and email correspondence to schools in the catchment area. Participants were self-selected, with numbers for each workshop group capped at 15. Groups were not matched for any demographics, including gender, age, professional background or primary roles in schools. Training courses were conducted at the two TTR partner organisations and were all jointly facilitated by a mental health clinician from OYH and a specialist teacher from Travancore School. During the study period, a total of four OYH clinicians and two Travancore teachers were involved in the running of training courses. Consistency in the delivery of the programs was maintained by continued joint program review and adherence to implementation and training guidelines (Travancore School \& Orygen Youth Health, 2013). 


\section{Results and discussion}

\subsection{Participant characteristics}

A total of 135 school welfare staff from state, independent, and Catholic secondary schools in the north-western area of Melbourne participated in TTR training sessions during the study period (Table 2 below).

Table 2. Characteristics of TTR participants

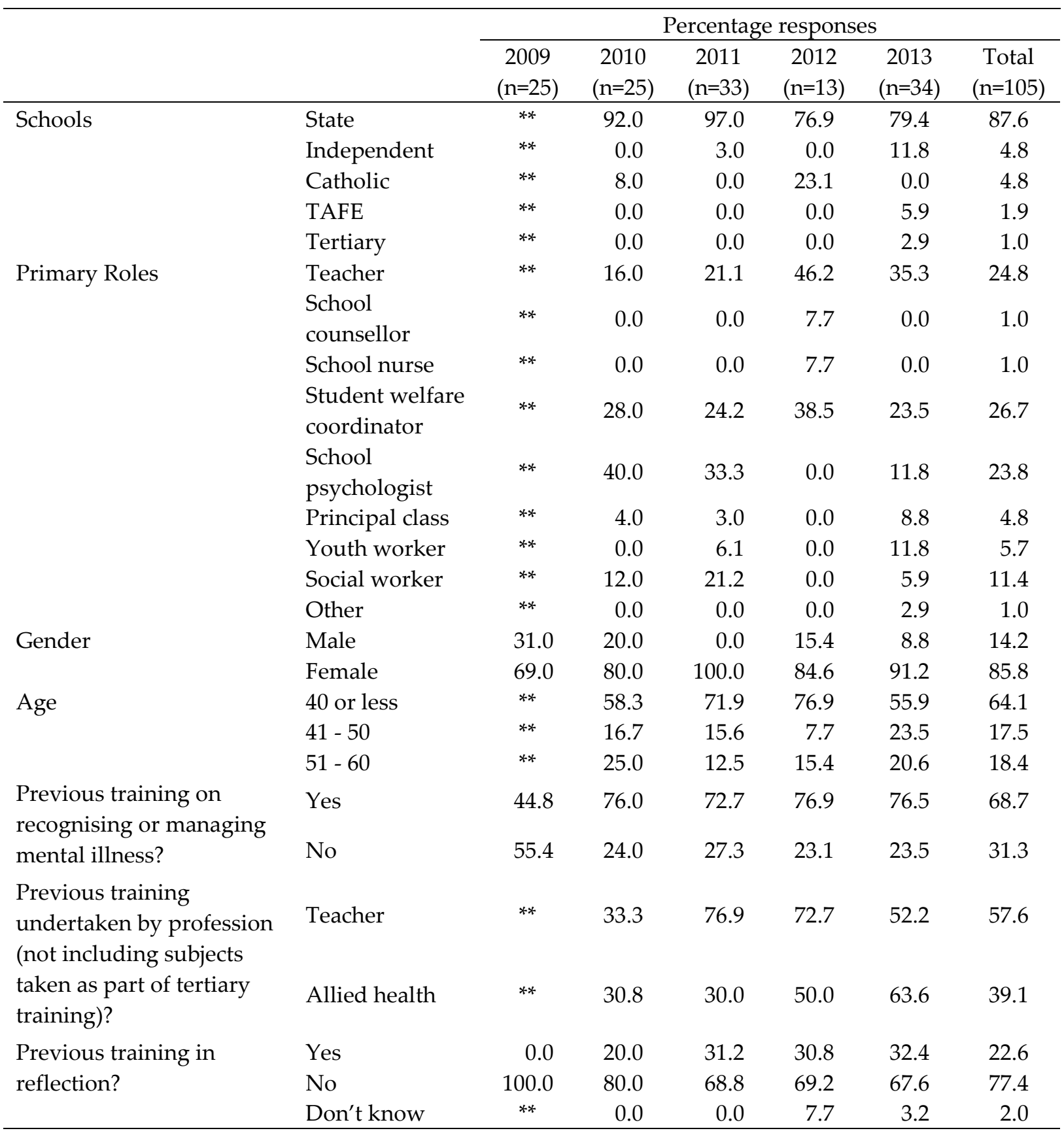

** Information not collected

The most common primary roles of participants were student welfare coordinator $(26.7 \%)$, teacher $(24.8 \%)$, and school psychologist $(23.8 \%)$. Significantly more female welfare staff participated than males (ratio 6:1). Whilst on average more than three-quarters of participants (with exception of the cohort in 2009) reported that they did have previous mental health specific 
training, teaching staff (58.5\%) were slightly more likely to have attended additional training in mental health since completing tertiary education when compared with allied health staff $(42.7 \%)$. Even fewer participants reported training during their pre-service preparation (Table 2). Less than one quarter had previous training specific to reflection/reflective practice prior to commencing TTR.

\subsection{Changes in perceived "competence" and "confidence"}

Significant changes in the reported perceived "competence" of participants were observed between the first (T1) and final (T2) sessions of the TTR training program in relation to three of the five key interest areas (Table 3 below).

Table 3. Changes in percentages of participants who perceive themselves to be "competent" in relation to the study interest areas (a-e) across three time points: prior to the initial session (T1), at completion of the training (T2), and at three months following the final session (T3)

\begin{tabular}{|c|c|c|c|c|c|c|c|}
\hline & & \multicolumn{3}{|c|}{ Percentage "competent"* } & \multirow{2}{*}{$\begin{array}{l}\text { T1 vs T2 } \\
\text { vs T3 } \\
\text { P-value } \\
(\mathrm{n}=78)\end{array}$} & \multirow{2}{*}{$\begin{array}{l}\text { T1 vs T2 } \\
\text { P-value } \\
(\mathrm{n}=113)\end{array}$} & \multirow{2}{*}{$\begin{array}{c}\text { T1 vs T3 } \\
\text { P-value } \\
(\mathrm{n}=84)\end{array}$} \\
\hline & & $\begin{array}{c}\mathrm{T} 1 \\
(\mathrm{n}=135)\end{array}$ & $\begin{array}{c}\mathrm{T} 2 \\
(\mathrm{n}=113)\end{array}$ & $\begin{array}{c}\mathrm{T} 3 \\
(\mathrm{n}=84)\end{array}$ & & & \\
\hline a. & $\begin{array}{l}\text { In recognising mental health } \\
\text { problems in young people }\end{array}$ & 42.4 & 84.1 & 85.7 & $<0.001$ & $<0.001$ & $<0.001$ \\
\hline b. & $\begin{array}{l}\text { In helping a student with a mental } \\
\text { health problem }\end{array}$ & 28.4 & 68.1 & 73.8 & $<0.001$ & $<0.001$ & $<0.001$ \\
\hline c. & $\begin{array}{l}\text { In assessing for risk of suicide or } \\
\text { deliberate self-harm in young people }\end{array}$ & 34.3 & 72.6 & 77.4 & $<0.001$ & $<0.001$ & $<0.001$ \\
\hline d. & $\begin{array}{l}\text { In knowing about appropriate } \\
\text { interventions for mental health } \\
\text { problems }\end{array}$ & 26.3 & 67.3 & 69.9 & $<0.001$ & 0.464 & $<0.001$ \\
\hline e. & $\begin{array}{l}\text { In discussing mental health } \\
\text { problems with parents of young } \\
\text { people }\end{array}$ & 35.3 & 71.7 & 79.8 & $<0.001$ & 0.341 & $<0.001$ \\
\hline
\end{tabular}

The areas that did not show evidence of change between T1 and T2 included knowing about appropriate interventions for mental health problems and discussing mental health problems with the parents of young people; however, this changed between T1 and T3 where there was evidence of difference. Possible reasons for this might be the continued use of reflective practice beyond the initial training and the opportunity to use this process to explore different interventions and ways to communicate with parents. These suggested reasons are supported by the findings discussed in the section below, where participants noted that reflection allowed them to look at situations in a different way and develop strategies to support students. Respectively, "confidence" ratings were found to be significantly higher for all five key interest areas at the end of the TTR program and were maintained at T3 (Table 4 below). At the three month follow-up (T3), "competence" and "confidence" self-assessments were found to be 
maintained or increased across all five key interest areas, compared to the beginning of the training (T1).

Table 4. Changes in percentages of participants who perceive themselves to be "confident" in relation to the study interest areas (a-e) across three time points: prior to the initial session (T1), at completion of the training (T2), and at three months following the final session (T3)

\begin{tabular}{|c|c|c|c|c|c|c|c|}
\hline & & \multicolumn{3}{|c|}{ Percentage "confident"* } & \multirow{2}{*}{$\begin{array}{l}\text { T1 vs T2 } \\
\text { vs T3 } \\
\text { P-value } \\
(\mathrm{n}=78)\end{array}$} & \multirow{2}{*}{$\begin{array}{l}\text { T1 vs T2 } \\
\text { P-value } \\
(\mathrm{n}=113)\end{array}$} & \multirow{2}{*}{$\begin{array}{l}\mathrm{T} 1 \text { vs T3 } \\
\mathrm{P} \text {-value } \\
(\mathrm{n}=84)\end{array}$} \\
\hline & & $\begin{array}{c}\mathrm{T} 1 \\
(\mathrm{n}=135)\end{array}$ & $\begin{array}{c}\mathrm{T} 2 \\
(\mathrm{n}=113)\end{array}$ & $\begin{array}{c}\mathrm{T} 3 \\
(\mathrm{n}=84)\end{array}$ & & & \\
\hline a. & $\begin{array}{l}\text { In recognising mental health } \\
\text { problems in young people }\end{array}$ & 40.6 & 82.4 & 84.7 & $<0.001$ & $<0.001$ & $<0.001$ \\
\hline b. & $\begin{array}{l}\text { In helping a student with a mental } \\
\text { health problem }\end{array}$ & 27.8 & 68.5 & 74.1 & $<0.001$ & $<0.001$ & $<0.001$ \\
\hline c. & $\begin{array}{l}\text { In assessing for risk of suicide or } \\
\text { deliberate self-harm in young people }\end{array}$ & 26.3 & 70.4 & 75.3 & $<0.001$ & $<0.001$ & $<0.001$ \\
\hline d. & $\begin{array}{l}\text { In knowing about appropriate } \\
\text { interventions for mental health } \\
\text { problems }\end{array}$ & 27.8 & 77.8 & 78.6 & $<0.001$ & $<0.001$ & $<0.001$ \\
\hline e. & $\begin{array}{l}\text { In discussing mental health problems } \\
\text { with parents of young people }\end{array}$ & 33.6 & 72.2 & 71.4 & $<0.001$ & $<0.001$ & $<0.001$ \\
\hline
\end{tabular}

"Percentage "confident": Percentage of participants who chose the options "quite a bit" to "extremely" confident in the questions.

\subsection{Recognition of mental health disorders}

There was no evidence of change in the knowledge of participants in the recognition of mental health disorders, with the exception of psychosis, from T1 to T2 ( $=3.64$ vs $\bar{x}=4.03, p=0.015)$. While there was a slight increase in correct responses between T1 and T2 for all disorders, this increase was not maintained at T3. For the mental health disorders of depression, anxiety and eating disorders, the majority of participants (89\%) scored $75 \%$ or more of the responses correctly at T1. This suggests a good level of initial knowledge, and this ceiling effect may explain the lack of improvement at T2 and T3. Comparative analysis of the teacher and allied health groups was also completed. Differences were found between teachers and allied health participants in relation to correct responses at T1 for eating disorders $(p=0.03$, Mann-Whitney $\mathrm{U}=1045.50, \mathrm{Z}=$ 2.11) and $\mathrm{T} 3$ for eating disorders ( $p=0.03$, Mann-Whitney $\mathrm{U}=493.50, \mathrm{Z}=2.17$ ), with allied health staff, on average, achieving more correct responses. It is important to note that this measure was researcher developed, and, while it may have ecological validity, results need to interpreted with caution. Also, these results are likely to be affected by the participant's caseload and mental health treatment experience with different disorders.

\subsection{Perceived benefits of "reflective practice"}

Participants reported an increased skill level in their ability to reflect on their professional practice from T1 to T2 $\left(\mathrm{p}<0.001, \mathrm{x}^{2}(2)=21.123\right)$ and agreed that after the training they made additional time available for reflective practice in their work $\left(p=0.002, x^{2}(2)=12.760\right)$. At T2 and 
T3 participants were asked, "Overall, how useful do you think is reflective practice to your work?" At T2, 88\% of participants noted that reflective practice was "quite a bit" or "extremely" useful. This increased to $92 \%$ of participants at T3. Participants were also asked to what extent they agreed that reflective practice helped with stimulating new ideas, utilising strengths, moving from reactive to proactive practice, celebrating success and feeling more connected and supported in their work. At T1, there were high levels of agreement from participants that reflective practice helped with stimulating new ideas about how to enhance skills and practice $(88.8 \%)$, utilising their strengths more effectively (90\%) and making them feel more connected and supported in their work across the three time points (85.1\%). Responses with an increased level of agreement over the period of training included: moving from reactive to proactive practice $\left(\mathrm{x}^{2}(2)=10.294, \mathrm{p}=0.006\right)$ and providing participants with an opportunity to celebrate their own successes $\left(x^{2}(2)=11.673, p=0.003\right)$. This suggests that while participants came to training with some preconceived ideas about the use reflective practice, training participation highlighted additional benefits of reflective practice.

\subsection{Changes to professional practice and reflection}

Upon completion of the TTR series, participants were asked to comment on changes they had made to their use of reflection, their professional practice, and barriers to reflection. Changes in the use of reflective practice noted by participants fell into three main categories:

1) Reflective practice becoming part of everyday work. This is illustrated by comments such as, "I try to make time to reflect at the end of the day with a colleague and it has also made me realize the positive things that I do as well," and "[t]here wasn't an opportunity previously to engage in reflection, but I have now been reflecting with my partner from the course," and "I have been more conscious of incorporating reflection into my daily routine and try to spend more time, albeit at home, reflecting on what's working well and not so well with students." These comments suggest that participants find reflective practice useful and have modified the approach in a way that works for them.

2) Improvements in professional skills and practice. Participants' comments that support this include, "I am more confident in completing risk assessments for children I know have a history of suicidal thoughts," and "[I] do a self-questionnaire [with students] and discuss mental health symptoms and investigate responses."

3) Use of reflection to understand mental health needs of students and as a new work practice. This is illustrated by comments including, "[I] feel more comfortable sitting with complex issues - don't feel the need to come up with immediate solutions," and "I have made time to reflect on my practice with someone outside of school." Participants also commented on accessing support in their use of referrals to other agencies, such as "I believe I am now asking many more questions of the students and getting better and more detailed info [sic] them making more appropriate referrals," and finding relevant resources, for example, "I search for information from reliable websites, such as beyondblue and OYH."

Participants also noted that reflection had allowed them to look at situations in a different way and develop strategies to support students. For example, "I have a few students who I have found challenging and difficult to engage. I dedicated time to reflecting on what about them/the case I found challenging, as well as my comfort level in getting creative with students to get them engaged," and "I am trying at the end of each week to reflect on the week; what happened; ask 
whether I handled situations well and what I could do differently." Lastly, participants identified devoting more time to using reflective practice. This was evident in comments such as, "I began to increase the amount of time of reflection," and "[w]e make more time available to reflect; placed greater importance on it," and "[m]ore reflective practice - celebrating success rather than just focusing on negative experiences."

As with any change process, there are barriers to implementing and committing to the change. The two main barriers noted by participants included 1) finding the time to reflect, due to their own work role and school priorities, and 2) conflicting work priorities. Comments that highlight the issue of time as a barrier for reflection included:

"Time. There are approx [sic] 1000 students in this school. The wellbeing team doesn't see all of them, but we do see many, usually on an ongoing basis. There are days when there is not enough time to write case notes and do planning for next year. Unfortunately, something has to give and it was the personal reflection."

Conflicting priorities to making time for reflection were identified in statements including: "[T] he main obstacle is the school being under pressure in other areas and support staff having to be elsewhere."

\section{Conclusions}

This study investigated whether participation in the "Time to Reflect" (TTR) training program would enhance the self-efficacy of secondary school wellbeing personnel in recognising and responding to the mental health needs of students. Prior to commencing the course, fewer than half the participants perceived themselves as competent and confident in relation to the study interest areas. The areas where participants felt least competent and confident were in helping a student with mental health problems, assessing the risk of suicide or deliberate self-harm, and knowing appropriate interventions for mental health problems. After participating in TTR, results indicated that school wellbeing personnel felt significantly more competent and confident in recognising mental health problems in young people, helping students with a mental health problem, assessing risk of self-harm and suicide, knowing about appropriate interventions for mental health problems, and in talking to parents about mental health problems.

The majority of participants reported making changes to their use of reflection as a result of attending TTR. These changes included reflection becoming part of everyday practice, and reflection being used to consider alternative ways of working with students. Participants also noted that continued reflective practice had benefits for their work in the form of improved professional skills, better use of referral to outside agencies and an increased ability to understand the needs of students who exhibited mental health needs. Participants also agreed that reflective practice was helpful in promoting a sense of proactivity in their work, and that reflection could be used as a means of celebrating success. Whether there is a relationship between reported practice change and use of reflection cannot be answered by this study. However, based on previous research into the relationship between reflection and professional practice, we propose that there might have been a positive association between increased awareness and use of reflection and the continued development of professional practice (e.g. Bronstein, 2003).

Schools can be frontline agencies in supporting the early recognition of mental health disorders in students. Mental health education and training is a declared priority area for workforce development in Australian schools (Department of Health and Ageing, 2009; Department of Human Services, 2009) with evidence showing that training of school personnel 
can lead to more effective supports for students with mental health disorders (Cooper \& Cefai, 2013). Rothi and Leavey (2006) noted that teachers want professional development courses to improve basic recognition skills and that training should focus on mental health in the educational environment and not attempt to create mental health professionals out of teachers. Given the encouraging outcomes of this study, the TTR program might be ideally suited to meet this objective.

The co-facilitated approach to delivering TTR was an important part of the process. Hernandez and Blazer (2006, cited in Cooper \& Cefai, 2013) note that it is important for both educational and health professionals to reflect on the ways in which they can combine their efforts. Despite previous experiences (Rothi et al., 2008; Sedlak, 1997) the TTR program has demonstrated that an educational and mental health service can work together successfully to achieve a shared goal.

\section{Limitations and future outlook}

As the focus of this study was the evaluation of a training program, it did not have a control group, and results therefore need to be interpreted with caution. Participant attrition in responses at T2 and T3 also affected conclusions that could be drawn. As, following completion of the course, participants did not perceive themselves significantly more competent in knowing about "appropriate interventions for mental health problems" or "discussing mental health problems with the parents of young people," future training sessions could be modified to place additional emphasis on the development of skill in these areas. For example, more specific examples for how to talk to parents about mental health issues could be provided during each session and/or additional skill practice could be included between training sessions (e.g. participants could be asked to conduct a parent education session and reflect upon their performance). Similarly, there could be a greater focus on teaching participants about mental health interventions and requesting homework assignments to be completed in between sessions (e.g. for participants to read articles about interventions). However, any changes to the course would need to factor in the existing time commitments of school wellbeing staff so that these are not perceived as burdensome. Perhaps a useful way to assess how the training course could be modified is to ask participants at completion of the series how their learning outcomes could have been further improved and make changes in line with their recommendations. Further research is required to explore what elements of TTR are most strongly associated with changes in reported self-efficacy and professional practice, specifically in relation to the potential influence of reflective practice. This study is also not able to clarify whether greater self-efficacy and reported practice change actually translate to better outcomes for students. A randomised controlled trial would be ideal to validate present findings. Further research in this area would also benefit from the use of validated measures to assess participant knowledge of mental health symptoms and the use of reflective practice.

In terms of ways forward, this study provides initial evidence that the TTR program promotes competence and confidence of student wellbeing personnel in recognising and responding to the mental health needs of students, and that regular reflective practice may have benefits for continued professional development. The study also reiterates the importance of mental health and education services working together to achieve positive outcomes in training school wellbeing staff to identify and support students with mental health disorders.

\section{Compliance with ethical standards}


All procedures performed in studies involving human participants were in accordance with the ethical standards of the institutional and/or national research committee and with the 1964 Helsinki Declaration and its later amendments or comparable ethical standards. Informed consent was obtained from all individual participants included in the study.

\title{
Acknowledgments
}

This study was generously supported by the Block Family Research Grant (private donation). We would also like to acknowledge the contributions by Heather Miller, Cassie Redlich, Hok Pan Yuen, Annie Bruxner and Georgie Cox to the program development and evaluation.

\author{
Authors \\ Carsten Schley \\ Orygen Youth Health \\ carsten.schley@orygen.org.au \\ Lisa McKay-Brown \\ Melbourne Graduate School of Education \\ Judy Ring \\ Travancore School \\ Katherine Monson \\ Orygen Youth Health \\ Jo Robinson \\ Orygen Youth Health \\ Leanne Crothers \\ Orygen Youth Health \\ Joanne Moore \\ Travancore School \\ Publishing Timeline \\ Received 17 November 2015 \\ Accepted 30 January 2017 \\ Published 9 June 2017
}

\section{References}

Australian Institute of Health and Welfare (2007). Young Australians: Their health and wellbeing (Cat. no. PHE 87). Canberra, Australia: Australian Institute of Health and Welfare.

Australian Institute of Health and Welfare (2011). Young Australians: Their health and wellbeing (Cat. no. PHE 140). Canberra, Australia: Australian Institute of Health and Welfare.

American Psychiatric Association (1994). Diagnostic and statistical manual of mental disorders (4th ed.). Washington, DC: Author.

Atkins, S., \& Murphy, K. (1993). Reflection: A review of the literature. Journal of Advanced Nursing, 18, 1188-1192. https://doi.org/10.1046/j.1365-2648.1993.18081188.x

Atkins, S., \& Murphy, K. (1994). Reflective Practice. Nursing Standard, 8(39), 49-56. https://doi.org/10.7748/ns.8.39.48.s64 
Borntrager, C., Caringi, J., van den Pol, R., Crosby, L., O'Connell, K., Trautman, A., \& McDonald, M. (2012). Secondary traumatic stress in school personnel. Advances in School Mental Health Promotion, 5(1), 38-50. https://doi.org/10.1080/1754730X.2012.664862

Boud, D., Keogh, R., \& Walker, D. (Eds.), (1985). Reflection: Turning experience into learning. New York, NY: Kogan Page.

Bronstein, L. (2003). A model for interdisciplinary collaboration. Social Work, 48(3), 297-306. https://doi.org/10.1093/sw/48.3.297

Carlson, L., \& Kees, N. (2013). Mental health services in public schools: A preliminary study of school counsellor perceptions. Professional School Counseling, 16(4), 211-221. https://doi.org/10.5330/PSC.n.2013-16.221

Carroll, M., \& Gilbert, M. (2011). On being a supervisee: Creating learning partnerships (2nd ed.). London, England: Vukani.

Cooper, P., \& Cefai, C. (2013). Evidence-based approaches to social, emotional and behavior difficulties in schools. KEDI Journal of Educational Policy, Special Edition, 81-101.

Crawford, S., \& Caltabiano, N. (2009). The school professionals' role in identification of youth at risk of suicide. Australian Journal of Teacher Education, 34(2), 28-39. https://doi.org/10.14221/ajte.2009v34n2.3

Department of Health and Ageing (2009). Fourth National Mental Health Plan: An agenda for collaborative government action in mental health 2009-2014. Canberra, Australia: Commonwealth of Australia.

Department of Human Services (2009). Because mental health matters: Victorian Mental Health Reform Strategy 2009-2019. Melbourne, Australia: Department of Human Services.

Dunst, C. J., Trivette, C. M., \& Hamby, D. W. (2010). Meta-analysis of the effectiveness of four adult learning methods and strategies. International Journal of Continuing Education \& Lifelong Learning, 3(1), 91-112.

Gibbs, G. (1988). Learning by doing: A guide to teaching and learning methods. London, England: Oxford Polytechnic.

Graham, A., Phelps, R., Maddison, C., \& Fitzgerald, R. (2011). Supporting children's mental health in schools: Teacher views. Teachers and Teaching, 17(4), 479-496.

https://doi.org/10.1080/13540602.2011.580525

Hopkins, L. (2014). Schools and adolescent mental health: Education providers or health care providers? Journal of Public Mental Health, 13(1), 20-24. https://doi.org/10.1108/JPMH-07-2013-0050

Koller, J., \& Bertel, J. (2006). Responding to today's mental health needs of children, families and schools: Revisiting the preservice training and preparation for school-based personnel. Education $\mathcal{E}$ Treatment of Children, 29(2), 168-197.

Kothagen, F., \& Vasalos, A. (2005). Levels in reflection: Core reflection as a means to enhance professional growth. Teachers and Teaching: Theory and Practice, 11(1), 47-71.

https://doi.org/10.1080/1354060042000337093

Larrivee B. (2000). Transforming teaching practice: Becoming the critically reflective teacher. Reflective Practice, 1, 293-307. https://doi.org/10.1080/713693162

Lee, G., \& Barnett, B. (1994). Using reflective questioning to promote collaborative dialogue. Journal of Staff Development, 15(1), 16-21.

Mann, K., Gordon, J., \& MacLeod, A. (2009). Reflection and reflective practice in health professions education: A systematic review. Advances in Health Science Education, 14, 595-621. https://doi.org/10.1007/s10459-007-9090-2

Partridge, K. (2012). Exploring pastoral staff's experiences of their own emotional well-being in a secondary school. Educational and Child Psychology, 29(4) 121-132.

Pettitt, B. (2003). Effective Joint Working between Child and Adolescent Mental Health services (CAMHS) and Schools. London, England: British Government Department for Education and Skills.

Rothi, D. M., \& Leavey, G. (2006). Child and adolescent mental health services (CAMHS) and schools: Inter-agency collaboration and communication. Journal of Mental Health Workforce Development, 1(3), 32-40. https://doi.org/10.1108/17556228200600022 
Rothi, D. M., Leavey, G., \& Best, R. (2008). On the front-line: Teachers as active observers of pupils' mental health. Teaching and Teacher Education, 24(5), 1217-1231. https://doi.org/10.1016/j.tate.2007.09.011

Schley, C., McKay-Brown, L., Ring, J., Monson, K., \& Crothers, L. (2013). 'Time to Reflect': Enhancing the self-efficacy of secondary school wellbeing personnel in recognising and responding to mental health needs of students. Training Manual (1st ed.). Melbourne, Australia: Travancore School \& Orygen Youth Health.

Schön, D. (1987). Educating the reflective practitioner. San Francisco, CA: Jossey Bass.

Sedlak, M. W. (1997). The uneasy alliance of mental health services and the schools: An historical perspective. American Journal of Orthopsychiatry, 67, 349-62. https://doi.org/10.1037/h0080238

Srivastava, T. K., Waghmare, L. S., \& Mishra, V. P. (2015). Reflections: An approach to comprehensive learning in medical education. National Journal of Physiology, Pharmacy \& Pharmacology, 5(2), 153-156. https://doi.org/10.5455/njppp.2015.5.061220141

Trudgen, M., \& Lawn, S. (2011). What is the threshold of teachers' recognition and report of concerns about anxiety and depression in students? An exploratory study with teachers of adolescents in regional Australia. Australian Journal of Guidance and Counselling, 21(3), 126-141. https://doi.org/10.1375/ajgc.21.2.126

Vieira, M., Gadelha, A., Moriyama, T., Bressan, R., \& Bordin, I. (2014). Evaluating the effectiveness of a training program that builds teachers' capability to identify and appropriately refer middle and high school students with mental health problems in Brazil: An exploratory study. BMC Public Health, 14, 210. https://doi.org/10.1186/1471-2458-14-210

Walter, H., Gouze, K., \& Lim, K. (2006). Teachers' beliefs about mental health needs in inner city elementary schools. Journal of the American Academy of Child and Adolescent Psychiatry, 45(1), 61-68. https://doi.org/10.1097/01.chi.0000187243.17824.6c

Weist, M., Mellin, E., Chambers, K., Lever, N., Haber, D., \& Blaber, C. (2012). Challenges to collaboration in school mental health and strategies for overcoming them. Journal of School Health, 82(2), 97-105. https://doi.org/10.1111/j.1746-1561.2011.00672.x 


\section{Appendix 1: TTR self-assessment questionnaire}

Example shown was used at time point one (baseline).

\section{ORYGEN YOUTH HEALTH RESEARCH CENTRE}

\section{‘TIME TO REFLECT’ COURSE EVALUATION}

\section{QUESTIONNAIRE 1}

Thank you for taking the time to complete the following questionnaire. Your responses will help us ensure that the training we are providing is achieving its aims. Please be as honest as you can in your responses and remember any information that you give to us will remain confidential. The questionnaire should take about 15 minutes to complete. 
Name:

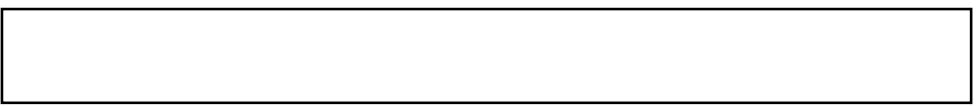

ID (office use)

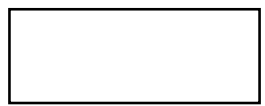

\section{SECTION 1: Demographic information}

1. Primary Roles (tick as many as apply)

Class Teacher $\square 1$ Student Welfare Coordinator $\square 2$ School nurse $\square 3$ Principal Class $\square 4$

Education Support Worker/Teacher's Assistant $\square 5$ Year Level Coordinator $\square 6$

Other $\square 7$ please specify:

2. What is your highest professional qualification?

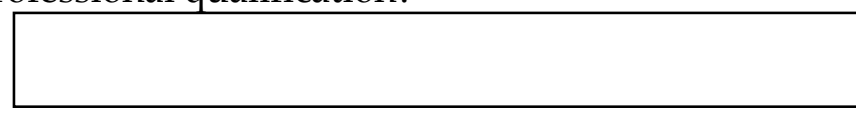

3. Sector: $\quad$ State / Independent / Catholic/Other - please specify:

4. Gender

Male $\square 1 \quad$ Female $\square 2$

5. Date of birth

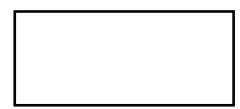

6. Why are you interested in doing this course?

7. Have you received previous training on recognising or managing mental illness?

Yes $\square 1 \quad$ No $\square 2$

If yes, please specify 
8. Have you received previous training on reflection/reflective practice?

Yes $\square 1 \quad$ No $\square 2$

If yes, please specify

\section{SECTION 2. Your ability to help someone with a mental health problem or deliberate self-} harm

a) How skilled do you feel in your ability to recognise mental health problems in young people?

Not at all $\square 1 \quad$ A little bit $\square 2 \quad$ Moderately $\square 3 \quad$ Quite a bit $\square 4 \quad$ Extremely $\square 5$

b) How skilled do you feel in helping a student with a mental health problem?

Not at all $\square 1 \quad$ A little bit $\square 2 \quad$ Moderately $\square 3 \quad$ Quite a bit $\square 4 \quad$ Extremely $\square 5$

c) How skilled do you feel in assessing for risk of suicide or deliberate self-harm in young people?

Not at all $\square 1 \quad$ A little bit $\square 2 \quad$ Moderately $\square 3 \quad$ Quite a bit $\square 4 \quad$ Extremely $\square 5$

d) How knowledgeable do you feel about appropriate interventions for mental health problems (e.g. supportive counselling, cognitive behaviour therapy)?

Not at all $\square 1 \quad$ A little bit $\square 2 \quad$ Moderately $\square 3 \quad$ Quite a bit $\square 4 \quad$ Extremely $\square 5$

e) How skilled do you feel discussing mental health problems with parents of young people at your school?

Not at all $\square 1 \quad$ A little bit $\square 2 \quad$ Moderately $\square 3 \quad$ Quite a bit $\square 4 \quad$ Extremely $\square 5$

f) How well do you think your school is able to respond to $\mathcal{E}$ meet the needs of students with a mental health problem?

Not at all $\square 1 \quad$ A little bit $\square 2 \quad$ Moderately $\square 3 \quad$ Quite a bit $\square 4 \quad$ Extremely $\square 5$ 


\section{SECTION 3. Your confidence in helping someone with a mental health problem or deliberate self-harm}

a) How confident do you feel in your ability to recognise mental health problems in students?

Not at all $\square 1 \quad$ A little bit $\square 2 \quad$ Moderately $\square 3 \quad$ Quite a bit $\square 4 \quad$ Extremely $\square 5$

b) How confident do you feel in helping someone with a mental health problem?

Not at all $\square 1 \quad$ A little bit $\square 2 \quad$ Moderately $\square 3 \quad$ Quite a bit $\square 4 \quad$ Extremely $\square 5$

c) How confident do you feel in assessing for risk of suicide or deliberate self-harm in students?

Not at all $\square 1 \quad$ A little bit $\square 2 \quad$ Moderately $\square 3 \quad$ Quite a bit $\square 4 \quad$ Extremely $\square 5$

d) How confident do you feel in your ability to respond to students with a mental health problem?

Not at all $\square 1 \quad$ A little bit $\square 2 \quad$ Moderately $\square 3 \quad$ Quite a bit $\square 4 \quad$ Extremely $\square 5$

e) How confident do you feel discussing mental health problems with parents of students at your school?

Not at all $\square 1 \quad$ A little bit $\square 2 \quad$ Moderately $\square 3 \quad$ Quite a bit $\square 4 \quad$ Extremely $\square 5$

\section{SECTION 4: Reflection/reflective practice}

"Reflection" is the ability to review our skills and knowledge in a constructive manner, thus leaving us with ideas about how to enhance our skills and practice (Atkins, 1991).

a) How skilled do you feel you are at reflecting on your professional practice?

Not at all $\square 1 \quad$ A little bit $\square 2 \quad$ Moderately $\square 3 \quad$ Quite a bit $\square 4 \quad$ Extremely $\square 5$

b) To what extent do you agree that reflective practice can help with:

Stimulating new ideas about how to enhance your skills and practice?

Strongly disagree $\square 1$ Disagree $\square 2$ Uncertain $\square 3 \quad$ Agree $\square 4 \quad$ Strongly agree $\square 5$

Utilising your strengths more effectively?

Strongly disagree $\square 1$ Disagree $\square 2 \quad$ Uncertain $\square 3 \quad$ Agree $\square 4 \quad$ Strongly agree $\square 5$ 
'Moving' you from 'reactive' to 'proactive' practice?

Strongly disagree $\square 1$ Disagree $\square 2$ Uncertain $\square 3 \quad$ Agree $\square 4 \quad$ Strongly agree $\square 5$

Providing you with an opportunity to celebrate your successes?

Strongly disagree $\square 1 \quad$ Disagree $\square 2$ Uncertain $\square 3 \quad$ Agree $\square 4 \quad$ Strongly agree $\square 5$

Making you feel more connected and supported in your work?

Strongly disagree $\square 1 \quad$ Disagree $\square 2$ Uncertain $\square 3 \quad$ Agree $\square 4 \quad$ Strongly agree $\square 5$

c) To what extent do you agree that you make time for reflection in your work?

Strongly disagree $\square 1$ Disagree $\square 2$ Uncertain $\square 3 \quad$ Agree $\square 4 \quad$ Strongly agree $\square 5$

d) How much time do you allow for reflection in a regular working week? Please specify

e) Overall, how useful do you think is reflective practice to your work?

N/A $\square 0 \quad$ Not at all $\square 1 \quad$ A little bit $\square 2 \quad$ Moderately $\square 3 \quad$ Quite a bit $\square 4 \quad$ Extremely $\square 5$

f) Which of the following questions are reflective questions? Tick as many as you think apply.

1. What exactly happened?

2. What mental health disorder might the client present with?

3. What was I thinking and feeling?

4. What was good/not so good about the way I did things?

5. What do I say to the parents?

6. How do I fit it all in?

7. What would I do differently next time?
8. Where can I access resources?

9. What did I learn about the ways that I work?

10. Wait and see what happens next time?

11. What else could I have done in this situation?

12. How do I solve this problem?

13. Who to refer this to?

14. How to stop this behaviour from happening again? 


\section{SECTION 5: Recognition of mental health problems}

\begin{tabular}{|c|c|c|c|c|}
\hline $\begin{array}{l}\text { Mental Health I } \\
\text { Please place a cross next to all symptoms th } \\
\text { same symptom can be selected for more th } \\
\text { criteria for Major Depression, Generalised }\end{array}$ & $\begin{array}{l}\text { isorders } \\
\text { t you think cor } \\
\text { n one disorder. } \\
\text { nxiety, Anorexi }\end{array}$ & $\begin{array}{l}\text { ympton } \\
\text { spond to th } \\
\text { ymptoms ar } \\
\text { and Bulimi }\end{array}$ & $\begin{array}{l}\text { Check } \\
\text { relevant diso } \\
\text { based on the } \\
\text { Nervosa and }\end{array}$ & $\begin{array}{l}\text { ler. The } \\
\text { OSM-IV-R } \\
\text { chizophrenia. }\end{array}$ \\
\hline & $\begin{array}{c}\text { Depression } \\
\text { (11 items) }\end{array}$ & $\begin{array}{l}\text { Anxiety } \\
\text { (8 items) }\end{array}$ & $\begin{array}{l}\text { Eating } \\
\text { Disorder } \\
\text { (9 items) }\end{array}$ & $\begin{array}{c}\text { Psychosis } \\
\text { (7 items) }\end{array}$ \\
\hline Appetite changes & & & & \\
\hline Binge eating & & & & \\
\hline $\begin{array}{l}\text { Delusions - false beliefs that are not part } \\
\text { of the person's culture and do not change. } \\
\text { E.g. believing that others can hear your } \\
\text { thoughts }\end{array}$ & & & & \\
\hline Denial of seriousness of low body weight & & & & \\
\hline Depressed/sad mood & & & & \\
\hline $\begin{array}{l}\text { Difficulty concentrating or difficulty } \\
\text { making decisions }\end{array}$ & & & & \\
\hline Difficulty controlling anxiety or worry & & & & \\
\hline $\begin{array}{l}\text { Disorganised thinking - trouble } \\
\text { organising or connecting thoughts in a } \\
\text { logical way. }\end{array}$ & & & & \\
\hline $\begin{array}{l}\text { Dissatisfaction with body shape and } \\
\text { weight }\end{array}$ & & & & \\
\hline $\begin{array}{l}\text { Distorted perception of body weight or } \\
\text { shape }\end{array}$ & & & & \\
\hline Excessive anxiety or worry & & & & \\
\hline Fatigue, tired all the time & & & & \\
\hline Fear of becoming fat & & & & \\
\hline Feeling wound-up, tense or restless & & & & \\
\hline $\begin{array}{l}\text { Feelings of worthlessness or } \\
\text { excessive/inappropriate guilt }\end{array}$ & & & & \\
\hline $\begin{array}{l}\text { Flat affect (person talks with a dull } \\
\text { monotonous voice with no emotion) }\end{array}$ & & & & \\
\hline $\begin{array}{l}\text { Hallucinations - seeing, hearing, smelling, } \\
\text { or feeling things that no one else can see, } \\
\text { hear, smell, or feel. }\end{array}$ & & & & \\
\hline $\begin{array}{l}\text { Inappropriate compensatory behaviour } \\
\text { (self-induced vomiting, laxative abuse, } \\
\text { excessive exercise) }\end{array}$ & & & & \\
\hline Irritability & & & & \\
\hline $\begin{array}{l}\text { Lack of ability to begin and sustain } \\
\text { planned activities }\end{array}$ & & & & \\
\hline $\begin{array}{l}\text { Loss of interest or pleasure in most } \\
\text { activities }\end{array}$ & & & & \\
\hline Recurrent suicidal thoughts & & & & \\
\hline
\end{tabular}




\begin{tabular}{|c|c|c|c|c|}
\hline \multicolumn{5}{|l|}{$\begin{array}{l}\text { Refusal to maintain minimum healthy } \\
\text { body weight for age. }\end{array}$} \\
\hline \multicolumn{5}{|l|}{ Significant tension in muscles } \\
\hline \multicolumn{5}{|l|}{ Sleep disturbance } \\
\hline \multicolumn{5}{|l|}{$\begin{array}{l}\text { Speaking little even when forced to } \\
\text { interact }\end{array}$} \\
\hline \multicolumn{5}{|l|}{$\begin{array}{l}\text { Talking or moving more slowly/quickly } \\
\text { than normal }\end{array}$} \\
\hline \multicolumn{5}{|l|}{ Undue influence of weight } \\
\hline \multicolumn{5}{|l|}{ Weight changes } \\
\hline \multirow[t]{2}{*}{ Subscale Score } & $/ 11$ & 18 & 19 & $/ 7$ \\
\hline & $\begin{array}{l}\text { Depression } \\
\text { (11 items) }\end{array}$ & $\begin{array}{l}\text { Anxiety } \\
\text { (8 items) }\end{array}$ & $\begin{array}{c}\text { Eating } \\
\text { Disorder } \\
\text { (9 items) }\end{array}$ & $\begin{array}{c}\text { Psychosis } \\
\text { (7 items) }\end{array}$ \\
\hline
\end{tabular}

\section{SECTION 6: Practice questions}

When presented with a young person who displays symptoms of mental illness...

1) Do you routinely screen students for suicide risk?

Yes $\square 1$ No $\square 2$

2) Do you use management plans for students who display symptoms of mental illness, self-harm or suicide risk?

Yes $\square 1$ No $\square 2$

3) Does your school have clear guidelines on the management of mental health problems among students?

Yes $\square 1 \quad$ No $\square 2$

4) Have you been able to assist in the development of clear guidelines regarding the management of mental health problems among students in your school?

Yes $\square 1 \quad$ No $\square 2$

\section{SECTION 7: Your experience of mental health problems}

We would like to know a bit about your experience of mental health problems in order to help us analyse this survey.

8.1 To your knowledge have any of the students in your school ever experienced:

a) A mental health problem?

Yes $\square 1 \quad$ No $\square 2 \quad$ Don't know $\square 3$


b) Deliberate self-harm?
Yes $\square 1$
No $\square 2$
Don't know

8.2 Have you had any personal experience of either a mental health problem or deliberate selfharm (i.e. yourself or a close friend or family member)?

Yes $\square 1 \quad$ No $\square 2 \quad$ Don't know $\square 3$

You have finished

THANK YOU!! 